\title{
PERAN PENGADILAN AGAMA KEDIRI DALAM PENYELESAIAN SENGKETA EKONOMI SYARIAH
}

\author{
PASCA PUTUSAN MAHKAMAH KONSTITUSI \\ NOMOR 93/PUU-X/2012
}

\author{
Ryana Marwanti \\ Universitas Muhammadiyah Surabaya
}

\begin{abstract}
The formulation of this thesis problem has three aspects, those are: (1) How is the authority of Religious Court of Kediri in resolving sharia economics disputes before the Decision of the Constitutional Court No. 93 / PUU-X / 2012, (2) How is the authority of the Religious Court of Kediri in the settlement of the sharia economics dispute after the Decision of the Constitutional Court No. 93 / PUU-X / 2012 (3) How is the role of Religious Court of Kediri in resolving the sharia economics dispute after the Constitutional Court Decision No. 93 / PUU-X / 2012?

The Research method used is qualitative method since this research describing an object in accordance with reality that is about the role of religious court of Kediri. Technique of collecting data is through interviewing and recording, while the data that has been obtained is analyzed by using descriptive analysis technique with deductive inductive pattern.

Based on the results of the research and the discussion done it can be summarized as follows: 1. The Judges of Religious Court of Kediri disagree if the sharia banking dispute must be resolved through the General Court. Based on the reason that the operational activity in Sharia Bank uses sharia principles, therefore if there is a dispute then the resolution is in the Religious Court instead of General Court. 2. The Judges of Religious Court of Kediri argue that it is true if the resolution of the sharia banking dispute is the absolute authority of the Court within the Religious Court. 3. The role of Kediri Religion Court in facing the existence of authority in the resolution of Shariah economic dispute after the Decision of the Constitutional Court No. 93 / PUU$\mathrm{X} / 2012$ is through following the technical training of sharia economic dispute resolution held by the Supreme Court and Financial Services Authority, following the education and training held by the courtroom of the Supreme Court and Ibnu Saud University of Saudi Arabia and reading many books related to the sharia economic.

On the basis of the results above, the researcher suggests to Judge of Religious Court of Kediri to be able to improve the quality especially in the field of sharia economy and the law of agreement and hopefully for the further researcher can analyze and examine more about sharia economic disputes both litigation and non litigation.
\end{abstract}

Key words: Religious Courts, Shari'a Economics, Constitutional Court 


\section{A. PENDAHULUAN}

Pasca lahirnya putusan Mahkamah Konstitusi Nomor 93/PUU-X/2012, hilanglah quo vadis tentang dualisme kewenangan penyelesaian sengketa ekonomi syari'ah melalui jalur litigasi. Peradilan Agama secara legal konstitusional menjadi satu-satunya institusi yang berwenang menyelesaikan sengketa ekonomi syariah melalui jalur litigasi. Berkairtan dengan kompetensi baru tersebut, akan sangat relevan untuk dikaji secara akademis tentang pemahaman hakim dan persiapan hakim pengadilan agama dalam menangani perkara ekonomi syari'ah ${ }^{1}$.

Mekanisme atau cara menyelesaikan sengketa dalam ekonomi syariah melalui jalur litigasi, sudah diatur sejak tahun 2006, yaitu pada pasal 49 Undang-Undang Nomor 3 Tahun 2006 tentang Peradilan Agama. Adapun sektor-sektor ekonomi syari'ah lebih luas lagi mencakup bank syari'ah, lembaga keuangan mikro syari'ah, asuransi syari'ah, reansuransi syari'ah, reksadana syari'ah, obligasi syari'ah, sekuritas syari'ah, pembiayaan syari'ah, dana pensiuan lembaga keuangan syari'ah dan bisnis syari'ah ${ }^{2}$.

$$
\text { Pada tahun 2008, }
$$

${ }^{1}$ Amran Suaidi dan Mardi Candra, Politik Hukum, Perspektif Hukum Perdata dan Pidana Islam serta Ekonomi Syari'ah, (Jakarta : Prenada Media, 2016), hal.434

2 Direktorat Jendral Badan Peradilan Agama Mahkamah Agung RI. Himpunan Peraturan Perundang-undangan di Lingkungan Peradilan Agama. (Jakarta : Mahkamah Agung, 2006). hal. 23 disahkan pula Undang-Undang Perbankan Syariah yaitu No. 21 Tahun 2008 tentang Perbankan Syariah yang bertujuan untuk mengatur segala ketentuan mengenai perbankan syariah, baik itu mengenai transaksi yang boleh dilakukan sampai proses penyelesaian sengketa juga sudah diatur secara jelas dalam undangundang ini.

Setelah Undang-Undang No. 21 Tahun 2008 tentang Perbankan Syariah ini muncul, maka muncul pula kontradiksi kewenangan absolut dalam penyelesaian sengketa perbankan syariah melalui jalur litigasi. Pada pasal 55 ayat (1), ayat (2) dan ayat (3), yang berbunyi :

Pasal 55

(1) Penyelesaian sengketa perbankan syariah dilakukan oleh pengadilan dalam lingkungan Peradilan Agama.

(2) Dalam hal para pihak telah memperjanjikan penyelesaian sengketa selain sebagaimana dimaksud pada ayat (1) penyelesaian sengketa dilakukan sesuai dengan isi akad.

(3) Penyelesaian sengketa sebagaimana dimaksud pada ayat (2) tidak boleh bertentangan dengan prinsip syariah (Undang-Undang No. 21 Tahun 2008 tentang Perbankan Syariah) ${ }^{3}$

Dirasa telah bertentangan dengan penyelesaian sengketa yang telah diatur dalam Undang-

3 Khosyi'ah, Fiqh Muamalah Perbandingan, (Bandung : Pustaka Setia, 2014). Hal. 297 
Undang Nomor 3 Tahun 2006 tentang Peradilan Agama. Pada penjelasan pasal 55 ayat (2) tersebut, mekanisme penyelesaian sengketa dapat dilakukan sesuai dengan isi akad dengan upaya antara lain: musyawarah, mediasi perbankan, melalui

BASYARNAS atau lembaga arbitrase lain dan atau melalui pengadilan dalam lingkungan Peradilan Umum. Sehingga kemunculan pasal 55 ayat (2) dan penjelasannya tersebut telah memberikan ruang kepada para pihak yang berakad untuk membuat pilihan forum (choice of forum) dalam menyelesaikan sengketa perbankan syariahnya melalui jalur litigasi yaitu dapat dilakukan di Pengadilan Agama sesuai Undang-Undang No. 3 Tahun 2006 tentang Peradilan Agama atau dapat dilakukan di Pengadilan Negeri sesuai UndangUndang No. 21 Tahun 2008 tentang Perbankan Syariah selama tidak bertentangan dengan prinsip syariah.

Dalam penjelasan pasal 55 ayat (2) Undang-Undang No. 21 Tahun 2008, yang menempatkan Pengadilan Negeri sebagai salah satu pilihan forum penyelesaian sengketa melalui jalur litigasi, mengakibatkan banyak pendapat yang tidak setuju akan hal ini karena secara peraturan hukum Islam, perbankan syariah menggunakan pedoman AlQuran dan Al-Hadits dalam setiap transaksinya. Pemeriksaan yang masuk kedalam Pengadilan Negeri secara keseluruhan khususnya menggunakan hukum acara perdata sama sekali tidak menggunakan hukum Islam. Secara kompetensi absolut
Pengadilan Negeri sama sekali tidak berwenang memeriksa bahkan mengadili sengketa ekonomi syariah. Akhirnya, dilakukanlah uji materi oleh Mahkamah Konstitusi mengenai pasal 55 Undang-Undang No. 21 Tahun 2008 tentang Perbankan Syariah beserta pasal penjelasnya terhadap UndangUndang Dasar 1945. Dikarenakan pada pasal tersebut dianggap bertentangan dengan hak konstitusional warga negara untuk mendapatkan kepastian hukum sebagaimana amanah UndangUndang Dasar 1945 yang termuat pada pasal 28D ayat (1) yang berbunyi: "Setiap orang berhak atas pengakuan, jaminan, perlindungan, dan kepastian hukum yang adil serta perlakuan yang sama dihadapan hukum". (Undang- Undang Dasar 1945).

Dari hasil uji materi tersebut, Mahkamah Konstitusi telah mengeluarkan putusan Nomor 93/PUU-X/2012 pada tanggal 29 Agustus 2013, yang menyebutkan bahwa pada penjelasan pasal 55 ayat (2) Undang-Undang No. 21 Tahun 2008 tentang Perbankan Syariah tidak mempunyai kekuatan hukum mengikat. Sehingga menimbulkan kepastian hukum dalam proses penyelesaian sengketa perbankan syariah melalui jalur litigasi. (Bagian penutup Putusan Mahkamah Konstitusi No. 93/PUU-X/2012. Proses penyelesaian sengketa perbankan syariah melalui jalur litigasi diselesaikan melalui lembaga peradilan, yaitu Pengadilan Agama. Apapun seluruh sengketa yang terjadi pada perbankan syariah yang berkaitan dengan transaksi 
ekonomi syariah, maka harus diselesaikan melalui pengadilan dalam lingkungan Peradilan Agama sebagai pilihan jalur litigasi.

Perubahan kewenangan mengadili tersebut dirasa telah merubah stigma publik. Awalnya mereka masih menganggap Pengadilan Agama adalah "pengadilan cerai" yang tentunya tidak cakap dalam menyelesaikan sengketa perbankan syariah. Kini, dengan adanya putusan Mahkamah Konstitusi mengenai kewenangan absolut yang diberikan kepada Pengadilan Agama sebagai satusatunya lembaga peradilan yang berwenang dalam penyelesaian sengketa ekonomi syariah melalui jalur litigasi, telah memberikan kesempatan yang besar kepada Pengadilan Agama untuk dapat membuktikan bahwa Hakim Pengadilan Agama adalah hakim di mata hukum dan ulama di mata umat, bukan penghulu di mata hukum dan ulama di mata umat.

Di wilayah Jawa Timur khususnya di Kediri, perbankan syariah juga sudah berkembang sangat pesat. Banyak bank-bank konvensional yang telah membuka cabang dengan menggunakan nama belakang "Syariah". Misalnya saja Bank Jatim Syariah, BRI Syariah, BNI Syariah, Bank Syariah Mandiri, Bank Mega Syari'ah dan sebagainya. Bank-bank tersebut banyak diminati oleh masyarakat Kediri baik. Sehingga terjadinya sengketa (dispute) perbankan syariah antara pihak yang berakad kemungkinan juga ada. Sampai saat ini di Pengadilan Agama Kediri ada 3 kasus sengketa ekonomi syariah yamg mendaftar di Pengadilan Agama Kediri, namun sebelum perkara diadili para pihak sudah mencabut perkaaranya.

Belum adanya kasus sengketa ekonomi syariah khususnya perbankan syariah yang diselesaikan di Pengadilan Agama Kediri sampai pada saat ini, menurut Hakim Pengadilan Agama Kediri dikarenakan kasus sengketa tersebut lebih banyak diselesaikan melalui jalur non litigasi atau Alternative Dispute Resolution $(A D R)$ seperti mediasi, negosiasi, dan sebagainya. Karena memang dalam proses penyelesaian sengketa perbankan syariah terdapat dua pilihan yaitu melalui Lembaga Peradilan (litigasi) atau melalui ADR (non litigasi).

Kaitannya dengan kewenangan absolut Pengadilan Agama Pasca diputuskannya Putusan Mahkamah Konstitusi Nomor 93/PUU-X/2012 tentang Penyelesaian Sengketa Perbankan Syariah oleh Mahkamah Konstitusi, tentunya hal ini akan berpengaruh juga pada peran Pengadilan Agama Kediri untuk dapat lebih baik dari sebelumnya. Serta memungkinkan munculnya berbagai persepsi para hakim Pengadilan Agama Kediri tentang adanya putusan tersebut. Baik itu dari segi pemahaman dan pendapat, serta strategi- strategi yang dilakukan oleh Pengadilan Agama Kediri khususnya para Hakim Pengadilan Agama Kediri dalam menghadapi adanya kewenangan absolut dalam penyelesaian sengketa ekonomi syariah pasca Putusan Mahkamah Konstitusi tersebut.

Berdasarkan uraian tersebut diatas, 
peneliti termotivasi untuk mengangkat judul penelitian dan mengkaji lebih jauh tentang, "Peran Pengadilan Agama Kediri dalam Penyelesaian Sengketa Ekonomi Syariah Pasca Putusan Mahkamah Konstitusi Nomor 93/PUU-X/2012"

\section{B. Rumusan Masalah}

Berdasarkan uraian dari konteks penelitian yang telah peneliti paparkan diatas, maka fokus penelitian ini yaitu mengenai persepsi Hakim Pengadilan Agama Kediri mengenai kewenangan absolut dalam penyelesaian sengketa perbankan syariah melalui jalur litigasi pasca Putusan Mahkamah Konstitusi No. 93/PUU-X/2012. Dengan pertanyaan penelitian, sebagai berikut:

1. Bagaimana

kewenangan

Pengadilan Agama Kediri dalam penyelesaian sengketa ekonomi syariah sebelum Putusan Mahkamah Konstitusi No. 93/PUU-X/2012 ?

2. Bagaimana kewenangan

Pengadilan Agama Kediri dalam penyelesaian sengketa ekonomi syariah pasca Putusan Mahkamah Konstitusi No. 93/PUU-X/2012?

3. Bagaimana peran Pengadilan Agama Kediri dalam penyelesaian sengketa ekonomi syariah pasca Putusan Mahkamah Konstitusi No. 93/PUU-X/2012?

\section{Tujuan Penelitian}

Berdasarkan fokus dan pertanyaan penelitian diatas, maka tujuan penelitian ini adalah:

1. Untuk mendiskripsikan kewenangan Pengadilan Agama Kediri dalam penyelesaian sengketa ekonomi syariah sebelum Putusan Mahkamah Konstitusi No. 93/PUU-X/2012 ?

2. Untuk mendiskripsikan kewenangan Pengadilan Agama Kediri dalam penyelesaian sengketa ekonomi syariah pasca Putusan Mahkamah Konstitusi No. 93/PUU-X/2012?

3. Untuk mendiskripsikan peran Pengadilan Agama Kediri dalam penyelesaian sengketa ekonomi syariah pasca Putusan Mahkamah Konstitusi No. 93/PUU-X/2012 ?

\section{Manfaat Penelitian}

Adapun manfaat dari penelitian ini mencakup manfaat teoritis dan manfaat praktis.

1. Manfaat Teoritis

Hasil Penelitian ini diharapkan dapat memberi sumbangan terhadap ilmu hukum Islam pada umumnya dan ilmu hukum ekonomi syari'ah pada khususnya dan dapat menjadi bahan literatur bagi sivitas akademika Universitas Muhammadiyah Surabaya.

2. Manfaat Praktis

a. Hakim Peradilan Agama Hasil penelitian ini diharapkan dapat menjadi motivasi bagi Hakim peradilan agar menambah wawasan dan pengetahuan tentang hukum ekonomi syari'ah agar bisa menambah kepercayaan bagi lembaga keuangan syari'ah.

b. Lembaga keuangan syari'ah Hasil penelitian dapat menjadi rujukan bagi lembaga yang bergerak di bidang ekonomi syariah jika ada sengketa ekonomi syariah khususnya sengketa yang melibatkan bank syariah yang harus mereka selesaikan melalui pilihan jalur litigasi.

c. Para pihak mencari berperkara 
Hasil penelitian dapat menjadi rujukan bagi masyarakat atau pelaku transaksi ekonomi syariah jika ada sengketa ekonomi syariah yang harus mereka selesaikan melalui pilihan jalur ligitasi.

\section{E. Metode Penelitian}

1. Jenis Penelitian

Jenis penelitian pada penelitian ini adalah penelitian lapangan yang bertujuan untuk memperoleh informasi dengan cara tanya jawab secara tatap muka antara peneliti (sebagai pewawancara dengan atau tidak menggunakan pedoman wawancara) dengan subjek yang diteliti ${ }^{4}$ yaitu pimpinan dan Hakim serta panitera muda Pengadilan Agama Kediri.

Untuk mendapatkan informasi yang sesuai dengan harapan peneliti, maka dibutuhkan waktu yang relatif lama dalam melakukan proses wawancara yang sedetail-detailnya dan hal ini bisa berlangsung secara berulangulang untuk menjawab pertanyaan yang sudah didesain untuk mengetahui peran Pengadilan Agama Kediri. Peneliti memberikan kebebasan kepada para hakim untuk menjawab pertanyaan sesuai maksud mereka. Pertanyaan yang peneliti ajukan bisa tidak terstruktur, terbuka, dan sangat fleksibel. Bahkan bisa berkembang sesuai situasi yang sedang terjadi.

2. Pendekatan Penelitian

Pendekatan

yang

\footnotetext{
${ }^{4}$ Wiratna Sujarweni, Metodologi Penelitian-Bisnis \& Ekonomi (Yogyakarta: Pustakabarupress. 2015), hal.25.
}

digunakan pada penelitian ini adalah pendekatan kualitatif. Penelitian kualitatif sebagai prosedur penelitian yang menghasilkan data deskriptif berupa kata-kata tertulis atau lisan dari orang- orang atau perilaku yang dapat diamati, ${ }^{5}$ yaitu pimpinan, hakim dan panitera muda hukum Pengadilan Agama Kediri.

\begin{tabular}{lrr}
\multicolumn{2}{c}{ Penelitian } & yang \\
menghasilkan & data & deskriptif \\
maksudnya & yaitu & metode
\end{tabular} penelitian yang digunakan untuk menggambarkan semua data atau keadaan subjek penelitian mengenai peran Pengadilan Agama Kediri dalam penyelesaian sengketa ekonomi syariah pasca Putusan Mahkamah Konstitusi No. 93/PUU-X/2012, kemudian dianalisis dan dibandingkan berdasarkan kenyataan yang sedang berlangsung pada saat ini dan selanjutnya dapat memberikan informasi yang dapat dibermanfaatkan bagi perkembangan ilmu pengetahuan serta lebih banyak dapat diterapkan pada berbagai masalah terkait dengan penyelesaian sengketa ekonomi syariah.

Penelitian deskriptif secara garis besar merupakan kegiatan penelitian yang hendak membuat gambaran atau mencoba melihat suatu peristiwa atau gejala secara sistematis, faktual dengan penyusunan yang akurat. $^{6}$ Pendekatan kualitatif ini

${ }^{5}$ Lexy J. Moeleong, Metodologi Penelitian Kualitatif (Bandung: PT Remaja Rosdakarya), hal.

${ }^{6}$ Supardi, Metodologi Penelitian Ekonomi Dan Bisnis (Yogyakarta: UII Press. 2005), hal. 28 
digunakan karena beberapa pertimbangan, yaitu lebih bisa dan mudah menyesuaikan apabila berhadapan dengan kenyataan ganda, metode ini menyajikan hakekat hubungan antara peneliti dan subjek penelitian secara langsung dan metode ini lebih peka sehingga dapat menyesuaikan diri dan banyak penajaman pengaruh bersama terhadap polapola nilai yang dihadapi peneliti. ${ }^{7}$ Penelitian ini diarahkan untuk mengetahui peran Pengadilan Agama Kediri dalam penyelesaian sengketa perbankan syariah melalui jalur litigasi pasca adanya Putusan Mahkamah Konstitusi No. 93/PUU-X/2012 serta strategi-strategi yang telah disiapkan oleh para Hakim Pengadilan Agama Kediri untuk menghadapi perkara sengketa perbankan syariah pasca Putusan Mahkamah Konstitusi No. 93/PUU-X/2012. Penerapan pendekatan kualitatif dengan pertimbangan kemungkinan data yang diperoleh di lapangan berupa data dalam bentuk fakta yang perlu adanya analisis secara mendalam. ${ }^{8}$ Maka pendekatan kualitatif akan lebih mendorong pada pencapaian data yang bersifat lebih mendalam terutama dengan keterlibatan peneliti sendiri di lapangan. Dalam penelitian kualitatif, peneliti menjadi instrumen utama dalam mengumpulkan data yang dapat berhubungan langsung dengan peran Kediri dalam penyelesaian sengketa ekonomi syariah pasca

${ }^{7}$ Ahmad Tanzeh dan Suyitno, Dasar-dasar Penelitian (Surabaya: Elkaf. 2006), hal.116.

${ }^{8}$ Sugiyono, Memahami Penelitian

(Bandung: CV Alfabeta. 2005), hal.2.
Putusan Mahkamah Konstitusi No.93/PUU-X/2012.

\section{F. Hasil Penelitian}

Dengan adanya Putusan Mahkamah Konstitusi No. 93/PUU$\mathrm{X} / 2012$, maka choice of forum dalam penyelesaian sengketa ekonomi syariah sudah tidak ada lagi. Penyelesaian sengketa ekonomi syariah menjadi kewenangan absolut (mutlak) Peradilan Agama (secara litigasi) dan berimplikasi kepada para Hakim Pengadilan Agama Kediri selaku pejabat yang melaksanakan tugas kekuasaan kehakiman bagi rakyat pencari keadilan mengenai perkara sengketa ekonomi syariah di wilayah Kediri. Peran para Hakim Pengadilan Agama Kediri dalam menghadapi adanya pemberlakuan kewenangan absolut dalam penyelesaian sengketa ekonomi syariah pun sangat diperlukan. Berikut pernyataan para Hakim Pengadilan Agama Kediri mengenai peran yang disiapkan dalam menghadapi adanya kewenangan absolut dalam penyelesaian sengketa ekonomi syariah pasca Putusan Mahkamah Konstitusi No. 93/PUU-X/2012.

1) Drs. M. Zaenal Arifin, M.H

"peran para Hakim Pengadilan Agama Kediri khusunya saya sendiri selaku ketua pengadilan agama sebenarnya sudah ada sejak disahkannya UndangUndang No. 3 Tahun 2006 tentang Peradilan Agama yang memuat 9 kewenangan Pengadilan Agama, salah satunya bidang ekonomi syariah. Jadi, pasca Putusan Mahkamah Konstitusi No. 93/PUU-X/2012 tidak terlalu 
berpengaruh besar terhadap kesiapan-kesiapan Hakim Pengadilan Agama Kediri khususnya saya sendiri untuk menghadapinya. Contohnya saya sendiri. Dulu saya pernah didelegasikan untuk mengikuti pelatihan tentang ekonomi syariah yang diadakan oleh Mahkamah Agung. Selain mengikuti pelatihan, saya juga banyak belajar dan membaca buku-buku yang berkaitan dengan ekonomi syariah"

2) Drs. Abdul Rosyid,M.H.

"Pasca putusan Mahkamah Konstitusi No. 93/PUU-X/2012, untuk menghadapi adanya kewenangan absolut dalam penyelesaian sengketa perbankan syariah, peran yang saya lakukan selaku Hakim Pengadilan Agama antara lain mengikuti pelatihan-pelatihan tentang ekonomi syariah, diklat ekonomi syari'ah di Universitas Ibnu Saud Saudi Arabia, saling berdiskusi antar hakim, banyak membaca, dan belajar lagi. Apalagi sekarang sudah ditunjang dengan penambahan referensi- referensi mengenai ekonomi syariah di Perpustakaan Pengadilan Agama Kediri ini" 9

Dari pernyataan para Hakim Pengadilan Agama Kediri diatas, maka ditemukan bahwa pasca Putusan Mahkamah Konstitusi No. 93/PUU-X/2012 tidak terlalu berpengaruh pada

\footnotetext{
${ }^{9}$ Hasil wawancara dengan Drs. Abdul Rosyid, M.H. pada hari kamis tanggal 6 Juli 2017
}

para Hakim Pengadilan Agama Kediri. Karena memang sejak tahun 2006 dengan disahkannya Undang-Undang No. 3 Tahun 2006 tentang Peradilan Agama sudah disebutkan bahwa salah satu bidang yang menjadi kewenangan absolutnya yaitu bidang ekonomi syariah. Setelah dikuatkan dengan Putusan Mahkamah Konstitusi No. 93/PUU-X/2012, maka para Hakim Pengadilan Agama Kediri mempunyai peran yang dilakukan dalam menghadapi adanya kewenangan absolut dalam penyelesaian sengketa ekonomi syariah pasca Putusan Mahkamah Konstitusi No. 93/PUU-X/2012 antara lain yaitu: mengikuti pelatihanpelatihan tentang penyelesaian sengketa ekonomi syariah, khususnya pada perbankan syariah, banyak membaca referensi terkait dengan ekonomi syariah, terus belajar dan didukung dengan sering melakukan kegiatan diskusi antar hakim ketika berada di ruang hakim saat tidak bertugas di ruang sidang.

\section{G. Analisis Hasil Temuan}

Dengan adanya Putusan Mahkamah Konstitusi No. 93/PUU-X/2012, maka choice of forum dalam penyelesaian sengketa ekonomi syariah sudah tidak ada lagi. Penyelesaian sengketa ekonomi syariah menjadi kewenangan absolut (mutlak) Pengadilan dalam lingkungan Peradilan Agama (secara litigasi). Pihak-pihak yang melakukan akad dalam aktifitas perbankan syariah, yakni Bank Syariah dan Nasabah dapat 
membuat pilihan forum hukum (choice of forum) mengenai domisili Pengadilan Agama yang akan menyelesaikan sengketa. Misalkan di Pengadilan Agama Kediri atau di Pengadilan Agama Blitar.

Mengenai adanya putusan

Mahkamah Konstitusi tersebut, maka berimplikasi pada para Hakim Pengadilan Agama Kediri selaku pejabat yang melaksanakan tugas kekuasaan kehakiman bagi rakyat pencari keadilan mengenai perkara sengketa ekonomi syariah. Adanya peran oleh para Hakim Pengadilan Agama Kediri dalam menghadapi adanya pemberlakuan kewenangan absolut dalam penyelesaian sengketa ekonomi syariah pun sangat diperlukan. Adapun

peran Pengadilan Agama Kediri dalam menghadapi adanya kewenangan absolut dalam penyelesaian sengketa ekonomi syariah pasca Putusan Mahkamah Konstitusi No. 93/PUU-X/2012, adalah sebagai berikut:

a. Mengikuti pelatihan-pelatihan mengenai penyelesaian sengketa ekonomi syariah, khususnya perbankan syariah yang diadakan oleh Mahkamah Agung, Otoritas Jasa Keuangan dan Bank Indonesia;

b. Mengikuti diklat ekonomi syariah yang diadakan di Saudi Arabia atau di Balai Diklat Mahkamah Agung;

c. Banyak membaca referensi terkait dengan ekonomi syariah, khususnya perbankan syariah;

d. Saling berdiskusi antar hakim Pengadilan Agama ketika berada di ruang hakim.

Dengan adanya strategistrategi tersebut diatas, maka para Hakim Pengadilan Agama Kediri berusaha mempersiapkan diri untuk memeriksa dan mengadili sengketa ekonomi syariah melalui jalur litigasi. Dari hasil wawancara peneliti terhadap para Hakim Pengadilan Agama Kediri mengenai kesiapan-kesiapan para hakim, bahwa ada beberapa hakim yang belum begitu paham mengenai akad-akad dalam perbankan syariah dan kegiatan usaha syari'ah Mengenai produkproduk syariah seperti tabungan maupun pembiayaan yang menggunakan akad syariah seperti mudharabah, musyarakah, murabahah, wadiah, ijarah, dan sebagainya. Padahal dalam menentukan itu kasus sengketa ekonomi syariah atau bukan, adalah dilihat dari akad yang dibuat oleh para pihak. Oleh karena ada beberapa Hakim Pengadilan Agama yang belum paham mengenai hal tersebut, maka upaya yang dilakukan oleh Mahkamah Agung selaku lembaga peradilan yang paling tinggi, yaitu mengadakan pelatihan- pelatihan mengenai penyelesaian sengketa ekonomi syariah secara litigasi yang wajib diikuti oleh delegasi dari masingmasing lembaga Pengadilan Agama yang ada di wilayah Indonesia. Sehingga, para Hakim Pengadilan Agama dapat lebih paham mengenai kegiatan usaha syari'ah dan akad-akad dalam produk perbankan syariah. 


\section{BAB V}

\section{KESIMPULAN DAN SARAN}

\section{A. Kesimpulan}

Dari uraian pembahasan diatas, maka peneliti menyimpulkan dari hasil penelitian yang telah dilakukan di Pengadilan Agama Kediri adalah sebagai berikut:

1. Pemahaman dan pendapat Hakim Pengadilan Agama Kediri mengenai kewenangan absolut dalam penyelesaian sengketa ekonomi syariah sebelum putusan Mahkamah Konstitusi No. 93-PUU-X/2012, terjadi kontradiksi. Dimana dalam Undang-Undang No. 3 Tahun 2006 tentang Peradilan Agama pasal 49, kewenangan absolut dalam penyelesaian sengketa ekonomi syariah secara litigasi dilakukan di Pengadilan Agama. Kemudian pada UndangUndang No. 21 Tahun 2008 tentang Perbankan Syariah pasal 55, disebutkan bahwa penyelesaian sengketa ekonomi syariah secara litigasi boleh dilakukan di Pengadilan Agama atau di Pengadilan Negeri. Dari adanya dua ketentuan tersebut, para Hakim Pengadilan Agama Kediri berpendapat dengan adanya dua aturan tersebut maka muncul adanya choice of forum dalam penyelesaian sengketa ekonomi syariah secara litigasi. Para Hakim Pengadilan Agama Kediri tidak setuju apabila sengketa perbankan syariah harus diselesaikan melalui Peradilan Umum. Dengan alasan bahwa Bank Syariah itu kegiatan operasionalnya menggunakan prinsip syariah/akad-akad syar'ah, maka apabila ada sengketa yang menyelesaikan adalah hakim yang beragama Islam dan paham mengenai akadakad pada bank syariah. Sehingga lebih pas diselesaikan melalui Peradilan Agama bukan Peradilan Umum.

2. Mengenai Kewenangan Absolut dalam Penyelesaian Sengketa Ekonomi Syariah Pasca Putusan Mahkamah Konstitusi No. 93/PUU-X/2012, para Hakim Pengadilan Agama Kediri berpendapat bahwa memang sudah benar apabila penyelesaian sengketa ekonomi syariah merupakan kewenangan absolut (mutlak) Pengadilan dalam lingkungan Peradilan Agama. Dengan terbitnya putusan Mahkamah Konstitusi Nomor 93/PUU-X/2012, maka para pihak tidak lagi terpaku dalam menyelesaikan sengketanya secara non litigasi pada musyawarah, mediasi perbankan, arbitrase melalui Badan Arbitrase Syariah Nasional atau lembaga arbitrase lainnya, tetapi dapat juga menempuh proses nonlitigasi lainnya seperti konsultasi, negosiasi (perundingan), konsiliasi, mediasi non mediasi perbankan, pendapat atau penilaian ahli.

3. Peran Pengadilan Agama Kediri dalam Menghadapi Adanya Kewenangan Absolut dalam Penyelesaian Sengketa Ekonomi Syariah Pasca Putusan Mahkamah Konstitusi No. 93/PUU-X/2012 yang disiapkan para Hakim Pengadilan Agama Kediri adalah sebagai berikut : 
a. Mengikuti pelatihan teknis penyelesaian sengketa ekonomi syariah yang diadakan oleh Mahkamah Agung, Bank Indonesia dan Otoritas Jasa Keuangan serta Pengadilan Tinggi Agama Surabaya;

b. Mengikuti pendidikan dan pelatihan yang diadakan Balai Diklat Mahkamah Agung dan Universitas Ibnu Saud Saudi Arabia;

c. Banyak membaca buku yang berkaitan dengan ekonomi syariah;

\section{B. Saran}

Berdasarkan penelitian yang sudah dilakukan di Pengadilan Agama Kediri, maka dapat dikemukakan beberapa saran, yaitu:

1. Bagi Lembaga

Pengadilan Agama Kediri untuk dapat lebih meningkatkan kualitas para Hakim terutama dalam penyelesaikan sengketa ekonomi syariah. Sehingga, para Hakim Pengadilan Agama Kediri dapat membuktikan bahwa Hakim Pengadilan Agama adalah hakim yang bisa menyelesaikan perkara-perkara perdata tertentu seperti sengketa ekonomi syariah, bukan hanya menyelesaikan sengketa Nikah, talak, cerai dan rujuk saja.

2. Bagi Peneliti Selanjutnya

Mengingat penelitian yang peneliti lakukan ini masih jauh dari kesempurnaan, maka diharapkan bagi peneliti selanjutnya untuk dapat meneliti dan mengkaji dari berbagai segi dalam penerapan penyelesaian sengketa ekonomi syariah baik secara litigasi maupun non litigasi. 